Research Article

\title{
Analytical Study on Special Concretes with M20 \& M25 Grades for Construction
}

\author{
SK.Mohammad Rafi ${ }^{\dot{A}^{*}}$, B.Ambalal $^{\dot{\mathrm{B}}}$, B.Krishna Rao ${ }^{\dot{\mathrm{A}}}$ and Mohd Abdul Baseer ${ }^{\dot{A}}$

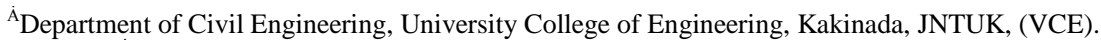 \\ ${ }^{\dot{B}}$ Department of Civil Engineering, Vardhaman College of Engineering (VCE)
}

Accepted 10 January 2014, Available online 01 February 2014, Special Issue-2, (February 2014)

\begin{abstract}
The disadvantage of conventional concrete is the high when the weight of concrete and density of the normal concrete is in the order of 2200 to $2600 \mathrm{~kg} / \mathrm{m}^{3}$. This heavy weight is some extent in uneconomical structural material. Attempts have been made in the past to reduce the self weight of concrete to increase the efficiency of concrete as a structural material. The light-weight concrete is defined as a concrete whose density varies from 300 to $1850 \mathrm{~kg} / \mathrm{m}^{3}$. We decrease the weight of concrete from fine aggregates or coarse aggregates can use light weight materials instead of coarse aggregates and fine aggregates .when replacing natural materials like pumice, diatomite, scoria, rice husk and saw dust, Artificial materials like brick bats, foamed slag and bloated clay.Mixing procedure for light-weight concretes may vary with different types of aggregates. The general practice for structural light-weight concrete is to mix the aggregate up to $2 / 3^{\text {rd }}$ of the water for a period of one minute to the addition of cement and sand. They are balanced by mixing water in the design of concrete grade like M20, M25. Mixing is done continuously for high rise building up to the completion of slab work. Usually 2 or more minutes are required to get uniform mixing for a good strength concrete. In insulating concrete, the aggregates are added at the end of mixing to decrease the degradation. Structural light-weight aggregate concrete is a concrete having 28 day compressive strength more than $17 \mathrm{MPa}$ and 28 day air dried unit weight not exceeding 1850 $\mathrm{kg} / \mathrm{m}^{3}$. Use of foam concrete has gained popularity not only because of the low density but also because of other properties mainly the thermal insulation property. Aerated concrete is made in the density range from $300 \mathrm{~kg} / \mathrm{m}$ to about $800 \mathrm{~kg} / \mathrm{m}$. Lower density grades are used for 3 insulation purposes, while medium density grades are used for the manufacture of building blocks or load bearing walls and comparatively higher density grades are used in the manufacture of prefabricated structural members in conjunction with steel reinforcement The third method of producing light concrete is to omit the fines from conventional concrete. No-fines concrete as the term implies, is a kind of concrete from which the fine aggregate fraction has been omitted. This concrete is made up of only coarse aggregate, cement and water. Very often only single sized coarse aggregate, of size passing through $20 \mathrm{~mm}$ retained on $10 \mathrm{~mm}$ is used. No-fines concrete is becoming popular because of some of the advantages it possesses over the conventional concrete. The single sized aggregates make a good no-fines concrete, which in addition to having large voids and hence light in weight, also offers architecturally attractive look. No-fines concrete can be used for a variety of purposes. It is used in large scale for load bearing cast in-situ external walls for single storey and multistoried buildings. This type of concrete has been used for temporary structures because of low initial cost and also for the ease with which it can be broken and reused as aggregate. Architects consider this as an attractive construction material. Owing to its slightly higher thermal insulating property, it be used for external walls for heat insulation. Because of rough texture, it gives a good base for plastering. Even if the outside surface of the no-fines concrete wall is subjected to rain beating, the inside of the wall will be free from dampness because of low capillary action on account of large voids. Where sand is not available, no-fines concrete should become a popular construction material. Finally the density of the concrete is nearly half of less than conventional concrete. The strength is nearly equals to the conventional concrete. The economy is good than conventional concrete. The workability is very good than conventional concrete.
\end{abstract}

Keywords: Cement type, Concrete mix proportion, Natural aggregates, Artificial aggregates, Strength of Concrete, Light-Weight Aggregate Concrete, Types of concrete.

\section{Introduction}

One of the disadvantage for high self weight of concrete is density. The normal concrete is in the order of 2200 to $2600 \mathrm{~kg} / \mathrm{m}^{3}$. This heavy self weight will make it to some

*Corresponding author: SK.Mohammad Rafi

DOI: http://dx.doi.org/10.14741/ijcet/spl.2.2014.62 extent an uneconomical structural material. Attempts have been made in the past to reduce the self weight of concrete and to increase the efficiency of concrete in structural material. The light-weight concrete and the concrete density varies from 300 to $1850 \mathrm{~kg} / \mathrm{m}^{3}$. There are many advantages of having low density .It helps in reduction of 
dead load, increases the progress of building, and lowers haulage and handling costs.

The weight of a building on the foundation is an important factor in design, particularly in the case of weak soil and tall structures. In framed structures, the beams and columns have to carry load of floors and walls. If floors and walls are made up of light-weight concrete it will result in considerable economy. Another most important characteristic of light-weight concrete is it has low relatively thermal conductivity. Thus the property of concrete improves its density. In extreme climatic conditions and also in case of buildings where airconditioning is to be installed, the use of light-weight concrete with low thermal conductivity will be of considerable advantage from the point of view of thermal comforts and lower power consumption. The adoption of light-weight concrete gives an outlet for industrial wastes such as clinker, fly ash, slag etc. which otherwise create problem for disposal. Basically there is only one method for making concrete light i.e., by the inclusion of air in concrete. This is achieved in actual practice by three different ways.

- By using the minerals the aggregates occurs cellular porous it is also called as light-weight aggregate.

- By introducing gas or air voids in concrete. This type of concrete is known as aerated concrete.

- By omitting sand fraction from the aggregate. This is called 'no-fines' concrete.

Light-weight concrete has become more popular in recent years owing to the tremendous advantages it offers over the conventional concrete. Modern technology and a better understanding of the concrete has also helped in the promotion of light-weight concrete. A particular type of light-weight concrete which is used in heavy structures is called as structural light-weight concrete. It is comparatively lighter than conventional concrete but at the same time it is very strong which is to be used for structural purposes.

It combines the advantages and discards the disadvantages of normal weight concrete. Perhaps this type of concrete will have great future in the future years. From these the concrete is divided into two types they are i) Light-weight concrete

ii) Aerated concrete.

These are mainly used in the 'no-fines' concrete for structures. Light-weight concrete is classified on the purpose of which it is used in structural light weight concrete, non-load bearing concrete and insulating concrete. The aerated concrete is also used for insulating purposes which is now being used for structural purposes sometimes it is used with steel reinforcement also. The aerated concrete is widely manufactured at Norway, Sweden, Denmark, Finland and Iceland. Where as in U.K., France, Germany and U.S.A. are preparing large scale of artificial light-weight aggregate and The light-weight aggregate concrete is widely used in construction works.

In some countries the natural dense graded aggregates are either in short supply or they are available at a considerable distance from the industrial cities. In such cases the use of locally produced light-weight aggregates are provided for economical solutions in site works. These factors are developed and widely used in construction. The varieties of industrial light-weight aggregates are varying in different qualities by the trade names of Leca (expanded clay), Aglite (expanded shale), Lytag (sintered pulverised sfuel ash), and Haydite (expanded shale).

\section{Natural Aggregates}

Natural light-weight aggregates are not found in many places and they are also not available in all areas in good quality and large quantity. As such they are not used very widely in making light-weight concrete. The natural lightweight aggregate is pumice. it is the only one which is used widely in construction.
i) PUMICE
ii) DIATOMITE
iii) SCORIA
iv) RICE HUSK

\section{Pumice}

These are rocks of volcanic origin which occur in many parts of the world. They are light enough and yet strong enough to be used as light-weight aggregate. Their lightness is due to the escaping of gas from the molten lava when erupted from deep beneath the earth's crest. Pumice is usually light coloured or nearly white and has a fairly even texture of interconnected cells.

Pumice is one of the oldest light-weight aggregates which are used in Roman structures. It is used after the washing. When it is weak the stronger aggregate is used in buildings.

\section{Diatomite}

This is a hydrated amorphous silica derived from the remains of microscopic aquatic plants which is called as diatom. Diatoms are also known as Kieselguhr. The deposits of this aquatic plants are formed at the depth of ocean bed. Subsequently when the ocean bed is raised the diatomaceous can observed on earth. It is available on land. In pure form diatomite has an average weight of 450 $\mathrm{kg} / \mathrm{m}^{3}$. But due to impurities, the naturally available diatomite may weight more than $450 \mathrm{~kg} / \mathrm{m}$. It has been pointed out earlier that diatomite is used as a workability agent and also as one of the good pozzolanic material.

Diatomite or diatomaceous earth can also be sintered in rotary kilns to make artificial light-weight aggregates.

\section{Scoria}

Scoria is also light-weight aggregate of volcanic origin which is usually dark in color and contains larger and irregularly shaped cells which are unconnected with each other. Therefore, it is slightly weaker than pumice. Volcanic Cinders are also loose volcanic products which are resembling artificial cinder. Sometimes saw dust is used as a light-weight aggregate in flooring and in the manufacture of precast blocks. A few difficulties are occurred when it is widely used. 
Saw dust affect adversely the setting and hardening of Portland cement owing to the content of tannins and soluble carbohydrates with saw dust manufactured from soft wood in the addition of lime to the mix in an amount. It is equal to $1 / 3^{\text {rd }}$ or half of the volume of cement which contained. But the above method Others methods such as boiling in water and ferrous sulphate solutions also have been tried to remove the effect of tannins, but the cost of the process limits its application. To delay the setting and hardening of concrete, addition of calcium chloride to the extent of about $5 \%$ by the weight of cement has been found to be successful.

The shrinkage and moisture movement of saw dust is also high. The practical mix is in the ratio of $1: 2$ to $1: 3$ i.e. , cement to saw dust by volume. Saw dust concrete is used in the manufacture of precast concrete blocks, jointless flooring and roofing tiles for buildings. Wood aggregate also has been tried for making concrete. The wood wool concrete is made by mixing wood shavings with Portland cement or gypsum for the manufacture of precast blocks. This has been used as wall panels for acoustic purposes.

\section{Rice Husk}

The rice husk, groundnut husk and bagasse are used as for the manufacture of light-weight concrete for special structures. It is taken as light weight aggregates.

\section{Artificial Aggregates}

Brick bats are another type of aggregate which are used in certain places where natural aggregates are not available and where they are very costly. The brick bat aggregates are not re light-weight aggregates because the concrete made with this aggregate. So it will not come under the category of light-weight concrete which is done by brickbats. Then the weight of such brick bat concrete will be less than the weight of normal concrete.

Wherever brick bat aggregates are used by they are made from slightly over burnt bricks which are very hard and absorb less water. Brick bat aggregates are also sometimes used in conjunction with high alumina cement for the manufacture of heat resistant concrete.

\section{Cinder, Clinker and Breeze}

The term clinker, breeze and cinder are used to cover the material partly or these particles arising from the combustion of coal. Now days the use of these materials like light- weight aggregate in the form of coarse or fine aggregate is getting more popular and it is wider use of pulverised coal rather than lumps of coal. Cinder aggregates are high drying shrinkage and high in moisture content. It is also used for making building blocks for partition walls and for making leveling for roofs and for plastering purposes in buildings.

By unburnt of coal particles the clinker and cinder aggregates are unsoundness. The unburnt particles give the presence of 15 to $25 \%$ of its strength. This high proportion of coal expand on wetting and contract on drying which is responsible for the unsoundness of concrete made with such aggregate.

\section{Foamed Slag}

Foamed slag is one of the most important types of lightweight aggregates. It is made by rapidly quenching blast furnace slag, a by-product, produced in the manufacture of pig iron. If the cooling of the slag is done with a large excess of water, granulated slag is formed which is used in the manufacture of blast furnace slag cement. If the cooling done with a limited amount of water, in such a way as to trip steam in mass, it produces a porous, honeycombed material which resembles pumice.

Sometimes, the molten slag is rapidly agitated with a limited amount of water and the steam and gas produced are made to get entrapped in the mass. Such a product is also called foamed slag or expanded slag. The texture and strength of foamed slag depends upon the chemical composition and the method of production. But in general, the structure is similar to that of natural pumice.

The foamed slag must be

i) Free from contamination of heavy impurities

ii) Free from volatile impurities such as coke or coal.

iii) Free from excess of sulphate.

In India foamed slag is manufactured in many steel mills. In Mysore. Iron and Steel Works at Bhadravati large quantity of foamed slag is being manufactured. Industries have come up near the steel mills to manufacture readymade building blocks and partition wall pnels. Such prefabricated items being lighter in weight, could be transported at comparatively low cost. Foamed slag is also used for the manufacture of precast RCC lintels and other small structural numbers. By controlling the density, foamed slag can be used for load bearing walls and also for the production of structural light-weight concrete.

\section{Bloated Clay}

When certain glass and shales are heated to the point of incipient fusion, they expand or what is termed as bloat to many times their original volume on account of the format ion of gas within the mass at the fusion temperatures. The cellular structure so formed is retained on cooling and the product is used as light-weight aggregate. Haydite, Rocklite, Gravelite, Leca, Aglite, Kermazite are some of the patent names given to bloated clay or shale manufactured in various western countries adopting different techniques. Central Building Research Institute of India (CBRI) has also developed a process technique for the manufacture of bloated clay for structural use. The experimental building constructed at CBRI using bloated clay as structural light-weight aggregate has been standing well. Sintered Fly Ash (Pulverised Fuel Ash) Fly ash is finely divided residue, comprising of spherical glassy particles, resulting from the combustion of powdered coal. By heat treatment these small particles can be made to combine, thus forming porous pellets or nodules which have considerable strength. 
The fly ash is mixed with limited amount of water and is first made into pellets and then sintered at a temperature of $1000^{\circ}$ to $1200^{\circ} \mathrm{C}$. The sintering process is nearly similar to that used in the manufacture of Portland cement. The fly ash may contain some unburnt coal which may vary from 2 to 15 per cent or more depending upon the efficiency of burning. The aim is always to make use of the fuel present in the fly ash and to avoid the use of extra fuel which incidentally improves the quality of sintered fly ash. Sintered fly ash is one of the most important types of structural light-weight aggregate used in modern times. In U.K., it is sold by the trade name Lytag. It has high strength/density ratio and relatively low drying shrinkage

\section{Strength of Concrete}

\begin{tabular}{|l|l|l|l|}
\hline $\begin{array}{l}\text { Type of } \\
\text { Concrete }\end{array}$ & $\begin{array}{l}\text { Bulk } \\
\text { density of } \\
\text { Aggregate } \\
\mathrm{kg} / \mathrm{m} 3\end{array}$ & $\begin{array}{l}\text { Mix Proportion } \\
\text { by volume } \\
\text { cement: } \\
\text { Aggregate }\end{array}$ & $\begin{array}{l}\text { Compressive } \\
\text { strengths Mpa }\end{array}$ \\
\hline Foamed slag & 900 & $1: 06$ & 21 \\
\hline $\begin{array}{l}\text { Rotary klin } \\
\text { expanded clay }\end{array}$ & 100 & $1: 08$ & $03-\mathrm{Apr}$ \\
\hline $\begin{array}{l}\text { Rotary klin } \\
\text { expanded slate }\end{array}$ & 950 & $1: 11$ & 14 \\
\hline Pumice & $500-800$ & $1: 06$ & \\
\hline
\end{tabular}

Very often light-weight concrete is made by the use of light weight aggregates. We have seen that different lightweight aggregates have different densities. Naturally when this aggregate is used, concrete of different densities are obtained. By using expanded perlite or vermiculite, a concrete of density as low as $300 \mathrm{Kg} / \mathrm{m}$ can be produced, and by the use of expanded slag, sintered fly ash, bloated clay etc., a concrete of density $1900 \mathrm{~kg} / \mathrm{m}$ can be obtained. The strength of the light-weight concrete may also vary from about $0.3 \mathrm{~N} / \mathrm{mm}^{3}$ to $240 \mathrm{~N} / \mathrm{mm}^{3}$.

A cement content of $200 \mathrm{~kg} / \mathrm{m}^{3}$ to about $500 \mathrm{~kg} / \mathrm{m}^{3}$ may be used. shows typical ranges of densities of concrete made with different light-weight aggregates, and Table 12.3 gives the typical properties of light-weight aggregate concrete. Strength of light-weight concrete depends on the density of concrete. Less porous aggregate which is heavier in weight produces stronger concrete particularly with higher cement content. The grading of aggregate, the water/cement ratio, the degree of compaction also effect the strength of concrete.

Most of the light-weight aggregate with the exception of bloated clay and sintered fly ash are angular in shape and rough in texture. They produce a harsh mix. Particular are should be taken to improve workability with the addition of excess of fine material, pozzolanic material or some other plasticizing admixtures. The strength of aggregate will also be influenced by the type of fine aggregates. For increasing the strength, for improving the workability and for reducing the water requirement, sometimes natural sand is also used.

\section{Workability}

Aggregate Concrete with light weight. Considerable attention is required to be given to the workability aspect for structural light weight concrete. In case of high slump and over vibration, the mortar goes down and aggregates are floated. This type of method is reverse of the normal weight concrete. In case of floor and deck slab the finishing operation will be very difficult. To avoid this difficulty the slump of concrete is maximum $100 \mathrm{~mm}$ to $120 \mathrm{~mm}$. if the slump is going to higher slump there is loss on account of continued absorption of water by aggregate. Light-weight concrete exhibits higher moisture movement than the normal weight concrete.

Concrete while wetting it swells more and it is drying shrinks more. The higher magnitude of drying. The concrete shrinkages coupled with lower tensile strength makes the light weight aggregate concrete to undergo shrinkage cracks. But the higher extensibility and lower modulus of elasticity help to reduce the tensile cracks. Since light-weight concrete contains large $\%$ of air, the light weight concrete is used for sound absorption \& sound proofing in halls, thermal insulations in factories. The coefficient of thermal expansion of concrete made with light-weight aggregate is generally much lower than ordinary concrete. Coefficient of Thermal Expansion made with Light Weight

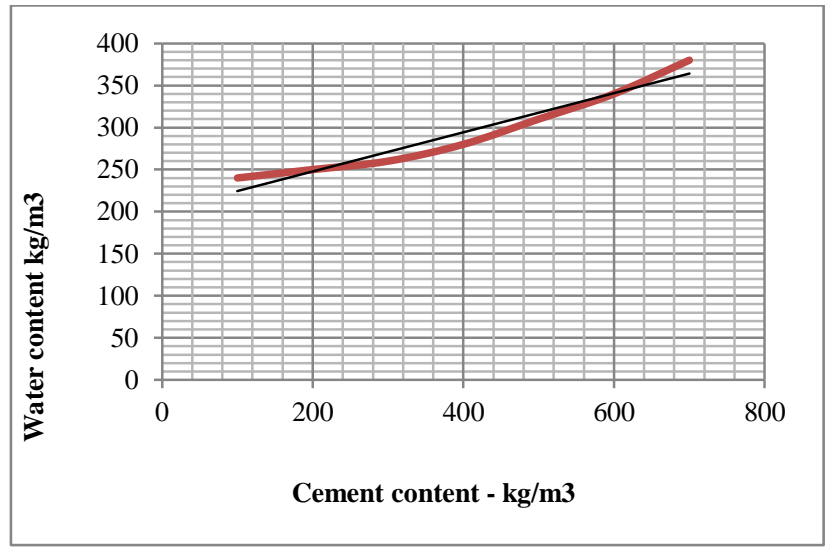

\section{Mixing Procedure}

Mixing procedure for light-weight concretes may vary with different types of aggregates. The general practice for structural light-weight concrete is to mix the aggregate and about $2 / 3$ of the mixing water for a period upto one minute prior to the addition of cement and the balance mixing water. Mixing is done continuously as required for homogeneity. Usually 2 or more minutes are required to get uniform mixing. In case of some insulating concrete, the aggregate is added at the end of mixing to minimize degradation. Mix design data have been prepared for several, proprietary light-weight aggregates available in the United Kingdom.

\section{Mix-Proportion}

No-fines concrete is generally made with the aggregate/cement ratio from 6:1 to 10:1. Aggregates used are normally of size passing through $20 \mathrm{~mm}$ and retained on $10 \mathrm{~mm}$. Unlike the conventional concrete, in which strength is primarily controlled by the water/ cement ratio, the strength of no-fines concrete, is dependent on the 
water/cement ratio, aggregate cement ratio and unit weight of concrete. Figure shows the relationship of compressive strength, water/cement ratio and aggregate/cement ratio for no-fines concrete.

The water/cement ratio for satisfactory consistency will vary between a narrow range of 0.38 and 0.52 . Water/cement ratio must be chosen with care. If too low a water/cement ratio is adopted, the paste will be so dry that aggregates do not get properly smeared with paste which results in insufficient adhesion between the particles. On the other hand, if the water/ cement ratio is too high, the paste flows to the bottom of the concrete, particularly when vibrated and fills up the voids between the aggregates at the bottom and makes that portion dense. This condition also reduces the adhesion between aggregate and aggregate owing to the paste becoming very thin.

No standard method is available, like slump test or compacting factor test for measuring/ the consistency of no-fines concrete. Perhaps a good, experienced visual examination and trial and error method may be the best guide for deciding optimum water/cement ratio. No-fines concrete, when conventional aggregates are used, may show a density of about 1600 to $1900 \mathrm{~kg} / \mathrm{m}$, but when nofines concrete is made by using light weight aggregate, 3 the density may come to about $360 \mathrm{~kg} / \mathrm{m}$.

No-fines concrete does not pose any serious problem for compaction. Use of mechanical compaction or vibratory methods are not required. Simple rodding is sufficient for full compaction. No-fines concrete does not give much side thrust to the formwork as the particles are having point to point contact and concrete does not flow. Therefore, the side of the formworks can be removed in a time interval shorter than for conventional concrete. However, formwork may be required to be kept for a longer time, when used as a structural member, as the strength of concrete is comparatively less. The compressive strength of no-fines concrete varies between $1.4 \mathrm{Mpa}$ to about $14 \mathrm{Mpa}$. Table 12.5 shows the compressive strength of no-fines concrete.

The bond strength of no-fines concrete is very low and, therefore, reinforcement is not used in conjunction with no-fines concrete. However, if reinforcement is required to be used in no-fines concrete, it is advisable to smear the reinforcement with cement paste to improve the bond and also to protect it from rusting.

\section{Types of concrete}

a) Gypsum concrete

b) High-strength concrete

c) Stamped concrete

d) High-performance concrete

e) Ultra-high-performance concrete

f) Self-consolidating concrete

g) Vacuum concrete

h) Shotcrete

i) Lime concrete

j) Cellular concrete

k) Roller-compacted concrete

l) Glass concrete m) Asphalt concrete

n) Rapid strength concrete

o) Rubberized concrete

p) Polymer concrete

q) Geopolymer concrete

\section{Properties of Foamed Concrete}

\begin{tabular}{|c|c|c|c|c|}
\hline \multirow{2}{*}{$\begin{array}{l}\text { Dry } \\
\text { Density } \\
(\mathbf{k g} / \mathbf{m 3})\end{array}$} & \multirow{2}{*}{$\begin{array}{l}\text { 7-days } \\
\text { Compressive } \\
\text { Strength } \\
(\mathrm{N} / \mathrm{mm} 2)\end{array}$} & $\begin{array}{l}\text { Thermal } \\
\text { Conductivity }\end{array}$ & \multirow{2}{*}{$\begin{array}{l}\text { Modulus } \\
\text { of } \\
\text { Elasticity } \\
(\mathrm{kN} / \mathrm{mm} 2)\end{array}$} & \multirow{2}{*}{$\begin{array}{l}\text { Drying } \\
\text { Shrinka } \\
\text { ge }(\%)\end{array}$} \\
\hline & & $(\mathbf{W} / \mathbf{m K})$ & & \\
\hline 400 & $0.5-1.0$ & 0.1 & $0.8-1.0$ & $\begin{array}{l}0.30 \\
0.35\end{array}$ \\
\hline 600 & $1.0-1.5$ & 0.11 & $1.0-1.5$ & $\begin{array}{l}0.22 \\
0.25\end{array}$ \\
\hline 800 & $1.5-2.0$ & $0.17-0.23$ & $2.0-2.5$ & $\begin{array}{l}0.20 \\
0.22\end{array}$ \\
\hline 1000 & $2.5-3.0$ & $0.23-0.30$ & $2.5-3.0$ & $\begin{array}{l}0.18 \\
0.15\end{array}$ \\
\hline 1200 & $4.5-5.5$ & $0.38-0.42$ & $3.5-4.0$ & $\begin{array}{l}0.11 \\
0.19\end{array}$ \\
\hline 1400 & $6.0-8.0$ & $0.50-0.55$ & $5.0-6.0$ & $\begin{array}{l}0.09 \\
0.07\end{array}$ \\
\hline 1600 & $7.5-10.0$ & $0.62-0.66$ & $\begin{array}{ll}10.0 & - \\
12.0 & -\end{array}$ & $\begin{array}{l}0.07 \\
0.06\end{array}$ \\
\hline
\end{tabular}

\section{Conclusions}

Density of the normal concrete is in the order of 2200 to $2600 \mathrm{~kg} / \mathrm{m}^{3}$.This heavy self weight will make it to some extent an uneconomical structural material. Attempts have been made in the past to reduce the self weight of concrete to increase the efficiency of concrete as a structural material. The light-weight concrete which is used for construction the density should varies from 300 to 1850 $\mathrm{kg} / \mathrm{m}^{3}$. The workability of the all concretes are very good than normal concrete. To get uniform mixing of concrete for construction it must be mix 5minutes minimum. The aggregates are added in insulating concrete at the end of mixing to minimize degradation of concrete. Structural light-weight aggregate concrete is a concrete having 28 days compressive strength more than $17 \mathrm{Mpa}$ and 28 day air dried unit weight not exceeding $1850 \mathrm{~kg} / \mathrm{m}^{3}$.

Finally the density of the concrete is nearly half of less than conventional concrete. The strength is nearly equals to the conventional concrete. The economy is good than conventional concrete.

\section{References}

Ozawa K., Kunishima, M., Maekawa, K. and Ozawa, K, Development of High Performance Concrete Based on the Durability Design of Concrete Structures. Proceedings of the second East-Asia and Pacific Conference on Structural Engineering and Construction (EASEC-2), Vol. 1, pp. 445 450, January 1989.

Specifications and guidelines for self-compacting concrete. published by EFNARC in February 2005.

Nan Su, Kung-Chung Hsu, His-Wen Chai, A simple mix design method for self-compacting concrete, Cement and Concrete Research, 6 June 2001, pp1799-1807.

S. Venkateswara Rao, M.V. Seshagiri Rao, P.Rathish KumarEffect of Size of Aggregate and Fines on Standard And 
High Strength Self compacting Concrete, Journal of Applied Sciences Research, 6(5): 433-442, 2010.

M.R.Arefi, M.R. Jahaveri, E. Mollaahmadi,(2011) Silica nanoparticle size effect on mechanical properties and microstructure of cement motar, Journal of American science.

A.A. Magsoudi, M.Magsoudi, and M. Noori, Effect of Nanoparticles on SCC, second international conference on sustainable construction materials and technologies.June 28, 2010.

Ashwani K. Rana, Shashi B RAna, AnjnaKumari and VaishnavKiran, Significance Of Nanotechnology in Construction Engineering. International journal of recent trends in engineering, Vol 1, No., May 2009.

G.Quercia\& H.J.H. Brouwers ; Application of Nano-Silica (nS) in Concrete Mixes, $8^{\text {th }}$ fib OhD symposium in Kgs. Lyngby, Denmark June 20-23, 2010.

CelikOzyildirim\& Caroline Zegetosky; Research Report on Laboratory investigation of Nanomaterials to Improve the strength and permeability of Concrete.
Mostafa. Khanzadi, Mohsen. Tadayon, Hamed. Sepehri and Mohammad. Sepehri, Influence of Nano-Silica Particles on Mechanical Properties and Permeability of Concrete. Second international conference on sustainable construction materials and technologies. June 28, 2010.

G.Quercia , PrzemekSpiesz, GotzHusken and Jos Browers, Effect of Amorphus Nano silica Additions on Mechanical and Durability Performance of SCC Mixtures. International Congress on Durability of Concrete.

Hall, C., 'Water sorptivity of mortars and concrete: a review', Magazine of Concrete Research 41 (147) (1989) 51-61.

Hui.Li, Hui-gang.Xiao, Jie.Yuan, 2004. Microstructure of cement mortar with nano-Particles. Composites, part B 185189.

K.L. Lin, W.C. Chang, D.F. Lin, H.L. Luo,M.C. Tsai, Effects of Nano-SiO2 and different ash particlesizes on sludge ashcement mortar, Journal of Environmental Management, 88, 4, 708-714, 2008

R.S.Chen, Q.Ye, 2002. Research on Comparison of Properties of Harddened Cement Paste Between Nano sio2 and Silica Fume add. Concrete research 1, 7-10. 